\title{
First report of tomato leaf curl New Delhi virus infecting pepper in Tunisia
}

\author{
Monia Mnari-Hattab ${ }^{1} \cdot$ Takoua Zaagueri $^{1} \cdot$ Semia Zammouri $^{1} \cdot$ Thouraya Rhim $^{2}$
}

Received: 23 November 2021 / Accepted: 7 January 2022 / Published online: 17 January 2022

(c) The Author(s) under exclusive licence to Società Italiana di Patologia Vegetale (S.I.Pa.V.) 2022

Keywords ToLCNDV $\cdot$ Pepper $\cdot$ Tunisia

Pepper (Capsicum annuum L.) is one of the main vegetable crops grown and consumed in Tunisia. The seasonal and late-season fresh pepper cultivars are grown in the open field, while the off-season product is grown under cover. Tomato leaf curl New Delhi virus (ToLCNDV), one of the major threats to cucurbits, is sporadically detected in tomato Tunisia (Zammouri et al. 2017). Since pepper, cucurbit and tomato crops overlap in the field, it is likely that pepper may become infected with ToLCNDV. Actually, pepper plants often show symptoms similar to tomato yellow leaf curl virus, such as severe yellowing, leaf curling, vein swelling, occasionally fruit skin roughness and brown necrosis of stem. To assess the presence of ToLCNDV in pepper, 24 symptomatic leaf samples were collected in Bizerte in 2017, Haouaria in 2019, and Monastir in 2020 from protected and open cultivations. Total DNA was extracted as previously described in (Mnari-Hattab et al. 2014). PCR was performed using total DNA and ToLCNDV specific primers MA2061 and MA2062 (Ruiz et al. 2015). An amplified product of approximately $890 \mathrm{bp}$ was obtained from 19 out of the 24 tested samples. Two amplified DNA products, one from Bizerte and one from Haouaria, were directly sequenced. The ToLCNDV sequences (OK184448, OK184449) shared more than $99 \%$ nucleotide identity to Tunisian ToLCNDV tomato isolates MF784759, MF784758, and pepper isolate 126 from Italy (MK756108), and 86\% to various peppers

Monia Mnari-Hattab

mmnari@gmail.com

1 Laboratoire de Biotechnologie Appliquée À L'Agriculture LR16INRAT06, Université de Carthage, Institut National de La Recherche Agronomique de Tunisie, Rue Hedi Karray, 1004 El Menzah 1, Tunis, Tunisia

2 Laboratoire d'horticulture LR16INRAT03, Université de Carthage, Institut National de La Recherche Agronomique de Tunisie, Rue Hedi Karray, 1004 El Menzah 1, Tunis, Tunisia isolates from India (MG597207 and MG597211). To the best of our knowledge, this is the first report of ToLCNDV infection on pepper in Tunisia.

\section{Data availability}

The sequencing data generated in this study were deposited in the Genbank and are freely available to any researcher.

Acknowledgements Takoua Zaagueri was financially supported by grants from GeMed Prima project section 2 financed by the Tunisian Ministry of Higher Education and Scientific Research (MERST).

\section{Declarations}

Informed consent All authors have approved the submission of this manuscript.

Conflict of interest The authors declare that they have no conflict of interest.

\section{References}

Mnari-Hattab M, Zammouri S, Pellegrin F, Gauthier N (2014) Natural occurrence of begomovirus recombinants associated with tomato yellow leaf curl disease co-existing with parental viruses in tomato crops and weeds in Tunisia. J Plant Pathol 96(1):195-200. https:// doi.org/10.4454/JPP.V96I1.043

Ruiz ML, Simon A, Velasco L, Garcia MC, Janssen D (2015) First report of tomato leaf curl New Delhi virus infecting tomato in Spain. Plant Dis 99(6):894. https://doi.org/10.1094/ PDIS-10-14-1072-PDN

Zammouri S, Zaagueri T, Eddouzi J, Belkhadhi MS, Hajlaoui MR, Mnari-Hattab M (2017) First report of tomato leaf curl New Delhi virus on tomato crop in Tunisia. J Plant Pathol 99(3):813

Publisher's Note Springer Nature remains neutral with regard to jurisdictional claims in published maps and institutional affiliations. 